\title{
Sosyalleşme ve Sosyalleşmenin Sosyal Medya Mecralarındaki Anlamsal ve İşlevsel Dönüşümü
}

\author{
Saniye Vatandaş (Öğr. Gör. Dr.) \\ Isparta Uygulamalı Bilimler Üniversitesi \\ saniyevatandas@isparta.edu.tr \\ Başvuru Tarihi: 15.01 .2020 \\ Yayına Kabul Tarihi: 02.05.2020 \\ Yayınlanma Tarihi: 24.07.2020 \\ https://doi.org/10.17680/erciyesiletisim.675531

\section{Öz}

Sosyalleşmenin birey ve toplum açısından yerine getirdiği farklı işlevler vardır. Birey sosyalleşme sayesinde insani nitelikler kazanmakta, toplumunun normal bir üyesi haline gelmekte, yaşam tarzını şekillendirmekte, geçmişin deneyimlerinden yararlanarak zaman kaybı yaşamamakta, farklı düzlemlerde söz konusu olabilecek risklerden uzak durmaktadır. İletişimin en temel aracı olan dili bile sosyalleşme sürecinde edinmekte ve geliştirmektedir. Ayrıca iletişime kapsam ve derinlik katan jest, mimik, beden dili gibi unsurları sosyalleşme sürecinde öğrenip uygulamaya aktarmaktadır. Sosyallik ve sosyalleşme açısından sosyal medya dikkate alındığında, sosyal medyanın sosyalliği, rutin dışı bir sosyalliktir. Sosyal medyanın sosyalliği ciddi tereddütleri gerektirecek, büyük sorular sormaya vesile olacak bir 'sosyalliktir'. Çünkü ilişki ve iletişim sınırlı, sığ ve çok daha önemlisi zaman ve mekândan büyük oranda kopmuş durumdadır. Sosyal medyada sınırlı bir iletişimden bahsetmek mümkünse de ilişkiden bahsetmek çok zordur. Bu çalışma, sosyalleşmenin sosyal medya mecralarındaki serüvenini konu edinmektedir. Ne gibi özelliklere sahip olduğu ve gidișatın seyrinin ne olduğu incelenmiștir. Konu bağlamında detaylı bir şekilde mevcut literatür incelenmiştir. Araştırma ile 'sosyalleşme' olgusunun hem işleyiş hem de niteliksel açıdan önemli düzeyde değișime uğradığı, ‘sosyalleşmenin' yeni bir anlam ve amaca evrildiği tespit edilmiştir.

Anahtar Kelimeler: Sosyalleşme, Sosyal Medya, Sanallaşma. 


\title{
Socialization, and The Conceptual and Functional Transformation of Socialization in Social Media Channels
}

\author{
Saniye Vatandaş (Lect. Ph.D.) \\ Isparta University of Applied Sciences \\ saniyevatandas@isparta.edu.tr
}

Date Received: 15.01.2020

Date Accepted: 02.05.2020

Date Published: 24.07.2020

https://doi.org/10.17680/erciyesiletisim.675531

\section{Abstract}

There are different functions of socialization in terms of the individual and society. The individual acquires human qualities thanks to socialization, becomes an ordinary member of the society, shapes his lifestyle, prevents loss of time by using the experiences of the past, and avoids the risks that may occur in different levels. He acquires and develops language, which is an essential tool of communication in the process of socialization.

Furthermore, he learns and practices the elements such as gesture, mimic, and body language, which add meaning and depth to communication in the process of socialization. When social media is considered in terms of sociality and socialization, the sociality of social media is a non-routine sociality. The sociality of social media is a 'sociality' that requires serious hesitations, and that will be a means of asking big questions because the relationship and communication are limited, shallow, and, more importantly, disconnected from time and space to a great extent. This research focuses on the adventure of socialization in social media channels. Its characteristics and the course of its journey have been investigated. The current literature has been examined in detail within the context of the issue.

Keywords: Socialization, Social Media, Virtualization. 


\section{Giriş}

İnsan, doğası gereği sosyal bir varlıktır. Toplumun dışında, tek başına yaşaması hem biyolojik ihtiyaçlarını hem de psikolojik ve sosyal ihtiyaçlarını karşılamayı imkânsız kılar. Biyolojik varlığını sürdürmeyi sağlayacak temel maddi ihtiyaçlar karşılanmış olsa bile, en temel insani özellikleri kazanamaz. Örneğin konuşamaz, iletişim kuramaz, duygularını kontrol edemez, zihinsel gelişimini gerçekleştiremez, zekâ problemi yaşar... Esasen doğum denen olay insanın tüm gelişim evrelerindeki önemli aşamalardan sadece birisi olup, insan doğduğu anda birçok bakımdan eksik bir varlıktır. Doğum sırasında biyolojik gelişiminin sadece temel gerekleri tamamlanmıștır. Biyolojik varlığının eksik boyutlarının yanı sıra, psikolojik ve sosyal gelişimi doğum sonrasında gerçekleşir. Bir başka söyleyişle insanın bedensel, zihinsel, duygusal, davranışsal... özelliklerinin oluşumu ve gelişimi iki ayrı ortamda gerçekleşmektedir; annesinin bedeninde ve toplumsal yapıda. İnsan yavrusunun biyolojik, psikolojik ve sosyal eksiklerini tamamlayıp yaşam boyu her aşamada 'normal' insan olabilmesi, annesinin vücudundan sonra toplumsal yapıda da gelişimini sürdürmesiyle mümkün olmaktadır (Borlandi \& Boudun, 2011, s. 830-833). Birinci aşama dokuz ay, ikinci aşama ise ömür boyu sürmektedir. Anne karnında temel biyolojik gelişimini sağlamamış çocuğun yaşaması mevcut eksikliğin niteliğine bağlı olarak ya imkânsız ya da ciddi biyolojik sorunların nedenidir. Sosyal yapıda ve bu yapıda egemen olan ilişkiler ağı içerisinde gerçekleşecek gelişimini henüz tamamlamamış birey ise hem birey ve hem de toplum açısından son derece önemli psikolojik ve sosyal sorunlara yol açar. Bu sebeple her birey sosyal ortamda bulunur ve sosyal ilişkiler ağında yerini alır. Yani sosyalleşme sürecine dâhil olur.

Sosyalleşmenin birçok işlevi vardır; bu işlevlerin en başında bireyin toplumuna uygun bir üye haline gelmesi vardır. Sosyalleşme (socialization), bireyin belli bir toplumun ve dolayısıyla kültürün mensubu haline gelmeyi ve gerçekten sosyal ve kültürel bir varlık olmayı öğrenip gereklerini büyük oranda yerine getirmeyi öğrendiği sürecin ismidir (Edgar \& Sedgwick, 2007, s. 337). Bu süreçte birey gerek toplumun norm ve değerlerini içselleştirerek, gerekse toplumsal rollerini (işçi, arkadaş, yurttaş, evlat, eş, anne, baba...) ve bu rollerin gereğini yerine getirmeyi öğrenerek toplumun 'normal' bir üyesi olur. Ancak sosyal ortamın aynı olması kişilikleriyle birbirinin aynısı bireylerin oluşumuna yol açmaz. Doğuştan gelen genetik özellikler, bireysel olarak mensubu olunan toplumsal birimlerin nitelikleri, bireysel ve sosyal ilişkilerdeki farklılıklar ve diğer bilinen ve bilinmeyen birçok faktör bir toplumun üyesi olan bireylerin birbirilerinden farklı kişiliklere sahip olmasına yol açar. Ancak kişilik farklılıkları toplum açısından detayda kalan bir durumdur. Bir toplumun üyesi olan bireyler arasında kişilik farklılıkları olsa bile, genel çerçevede dikkate alındığında bireyler kişilik özellikleri ve yaşam tarzları birbirlerine benzerlikler gösterirler. Bu da toplumlar arasındaki farklılığın nedeni olarak anlam kazanır.

Sosyalleşme sürecine etki eden ortam ve birimler yapısal ve işlevsel açıdan sabit değildir. Sayısal olarak değiştikleri gibi, işlevsel olarak da değişebilmektedirler. İşlevsel değişme açısından aile kurumu önemli bir örnektir. Aile kurumu zaman içerisinde hem nicel hem de nitel olarak önemli oranda değişmiştir. Bu değişim ise sosyalleșmenin en önemli faktörü olan ailenin bireyin sosyalleşmesindeki etki gücünü ve oranını değiştirmiştir. Zira büyük aile yapısının bireyin sosyalleşmesine katkısı ile çekirdek ailenin etkisi aynı değildir. Bunun yanında insanlık tarihinin önemli bir kısmında yer alamayan okul (eğitim kurumu), sosyalleşmenin faktörlerinde gerçekleşen sayısal artışın bir örneği olarak anlam kazanmaktadır. Aynen kitle iletişim araçları gibi. Bu da göstermektedir ki tarihsel süreçte sosyalleşmeyi sağlayan sosyal kurum ve birimlerin değişiminin yol açtığı boşluklar veya 
teknolojik gelişmenin oluşturduğu yeni imkân ve yaşam tarzları, sosyalleşme sürecinin faktörlerinde sayısal ve işlevsel değişmelere neden olmaktadır. Hatta sosyalleşmenin bizzat kendisinde değişime neden olabilmektedir. Bu açıdan internet teknolojisinin ürünü olan sosyal medya mecralarının bireylerin kişilik gelişimlerine etkisi önemlidir. Bugün itibarıyla gelinen son aşamada sosyalleşmenin sanallaşmasından, bir başka ifadeyle 'sanal sosyalleşme'den bahsedilebilmektedir. Artık sadece sosyalleşmeyi sağlayan faktörlerin değişiminden değil, daha fazlasıyla sosyalleşmenin bizzat kendisinde gerçekleşen niteliksel değişimden bahsedilebilmektedir. Sanal sosyalleşmenin birey ve toplum açısından yol açtığı değişimler ve yeni oluşumlar ise başlı başına önemli bir sorundur.

\section{Sosyalleşme}

Bireysel ve toplumsal açlardan oldukça karmaşık ve çok yönlü bir süreci ifade eden sosyalleşme, en kısa anlamıyla, biyolojik bir varlık olarak doğan insanın sosyo-kültürel bir şahsiyet haline evrilmesinin ismidir. Evrensel manada standart bir insan anlayışı olmadığ gerçeğini dikkate alarak ifade etmek gerekirse; sosyalleşme, 'insanlaşma' sürecidir. Birey sosyalleşirken hem toplumunun tipik bir üyesi olur, hem de toplumunun kültürel ölçütlerinde 'insan' olur. Dolayısıyla sosyalleşme bireyi ilgilendirdiği kadar, toplumu da ilgilendiren bir olgudur. Söyleşmenin bireysel boyutunda, bireyin içine doğduğu toplumun kültürünü tüm yönleriyle içselleştirerek (Marshall, 1999, s. 760; Edgar ve Sedgwick, 2007, s. 337), toplumuna uygun bir kişi haline gelmesi söz konusudur. Toplumsal boyutunda ise kültürel mirası yüklenmiş bireyler üzerinden toplumun süreklilik kazanması vardır.

Sosyalleşme potansiyeliyle doğan ve doğasının gereği olarak sosyalleşmek zorunda olan insan yavrusunun içine doğduğu toplumun bir üyesi haline gelebilmesi için bazı ön koşullara ihtiyaç vardır. Bunlardan birincisi, sosyalleşmenin hem beşiği hem de hedefi olan sosyal bir yapının bulunuyor olmasıdır. Birey ancak sosyal bir yapıda, o yapıdaki ilişkiler ağının içinde yer alarak sosyalleşebilir. Çünkü sosyalleşme soyut bir bilgilenme süreci değil, deneyimlenerek gerçekleşen bir süreçtir. Sosyalleşmenin gerçekleşebilmesi için gerekli olan ikinci ön koşul, çocuğun sosyalleşmesini ve toplumun bir üyesi olmasını sağlayacak gerekli ve yeterli biyolojik ve kalıtsal özelliklere sahip olması gerekmektedir. Zira önemli düzeyde kalıtımsal bozukluklara sahip olanlar ya hiç sosyalleşemezler ya da zihinsel, duygusal, davranışsal gelişimlerinde ciddi sorunlarla karşılaşırlar. Sözgelimi önemli düzeyde zihinsel bozukluğu olan bir çocuğun gerektiği şekilde sosyalleşebilmesi ya son derece güçtür ya da tümüyle imkânsızdır. Bundan da anlaşılacağı üzere biyolojik varlığımız yalnızca sosyalleşmeyi mümkün kılmamakta, aynı zamanda onu gerekli kılmaktadır. Sosyalleşmenin üçüncü ön koşulu bireyin öteki bireylerle birtakım ilişkiler kurma isteğine sahip olması ve bu yönde çaba göstermesidir. Birey bu ilişkiler dolayımında sevgi, saygı, merhamet, utanma, kıskançlık, sadakat, yardımseverlik, vefa, acıma, beğenilme, nankörlük, bencillik vb. duyguların eşlik ettiği deneyimler kazanır (Tolan, 1991, s. 32-33). Bunlar ise herhangi bir birey olmaktan çıkıp özel bir kişi olmanın temel taşları işlevini görür. Amerikalı sosyal psikolog C. H. Cooley (1864-1929), bu özelliğin sosyalleşmenin en önemli koşullarından birisi olduğuna dikkat çekmiş ve 'insanın yaratılışının', bu koşulun varlığına bağlı olduğunu ifade etmiştir. Cooley'e göre söz konusu özellikler insanın hayvanlardan ayrılıp özel bir varlık haline gelmesinde oldukça önemli özelliklerdir. Örneğin, fareye saldıran ve ona acı yaşatan bir kedi, acı yaşattığı farenin duygularından habersizdir. Sadece kendi duygularıyla hareket etmektedir. İlişkinin tek taraflı anlamı vardır. Dolayısıyla kedinin fare karşısında zalim/zorba olduğu söylenemez. Ancak mahkûma kötü muamele eden bir gardiyan, tutuklunun çektiği acının farkındadır. Bu sebeple de yaptığı zulümdür/zorbalıktır (Ülgen, 1983, s. 45). Cooley’e göre 
söz konusu duyguların evrensel bir standardı yoktur; ortaya çıkış şekilleri ve gerekleri kültürlere göre farklılık gösterse de varlıkları evrenseldir. Bireyin toplum içinde nasıl ve ne kadar sosyalleştiğinin göstergesi, toplumsal kurumlar ve birimler tarafından kendisine aktarılmış sosyal değerlerin ve normların, bireyin tutum ve davranışlarına yansıması ve bu davranışların gözlenebilirliği sayesinde bilinebilmektedir (Ergil, 1984, s. 62)

Birey toplum içinde, toplumsal birimlerin ve kurumların etkisi altında sosyalleşir. Sosyalleşmeyi sağlayan toplumsal birim ve kurumlar evrensel olmakla birlikte, sabit değildir. Zaman içerisinde sayılarında ve işlevlerinde değişmeler gerçekleşmiştir. Aile, din, ekonomi gibi temel toplumsal kurumlar zaman içinde hem yapısal hem de işlevsel olarak önemli oranda değişmiştir. Bu değişmeler toplumsal yapının işleyiş̧inde yeni durumların açığa çıkmasına yol açmıştır. Örneğin aile yapısındaki küçülme eğitim işlevinin aile kurumundan ayrılıp bağımsız bir kurum haline gelmesini sağlamıştır. Ayrıca yaşamın maddi/teknolojik koşullarında gerçekleșen değişmeler yeni ihtiyaçların oluşmasına yol açmış, bu da yeni toplumsal kurumların ve birimlerin oluşmasını sağlamıştır. $\mathrm{Bu}$ açıdan kitle iletişim araçları veya 'serbest zaman' (Türkçe de yaygın ismiyle 'boş zaman') kurumu önemli iki örnektir. İkisi de modern zamanlara özgüdür. Dolayıyla toplumsal yapıda ve toplumsal işleyişte gerçekleşen değişmeler ve yenilikler doğrudan sosyalleşmeyi de etkilemektedir.

Bugün itibarıyla dikkate alındığında sosyalleşmenin en önemli faktörlerinin aile, din, serbest zaman, eğitim, iktisat, siyaset kurumları olduğu anlaşılmaktadır. Toplumsal kurumların gerektirdiği veya mümkün kıldığı ebeveyn-çocuk, akraba, arkadaş ilişkileri, okul ve ticaret hayatı, kır ve kent ortamı, spor ve eğlenme faaliyetleri, kitle iletişim araçları... ise sosyalleşme süresinde etkin olan faaliyetler ve birimler olarak işlev görmektedirler.

Sosyalleşme ömür boyu devam eder. Fakat sosyalleşmenin hızı ve yoğunluğu yaşamın her aşamasında aynı değildir. Sosyalleşme, çocukluk yıllarında oldukça hızlı bir öğrenme sürecine eşlik etmekte, fakat ilerleyen yaşlarda yavaşlamaktadır. Fakat ileri yaşlarda olmak üzere bazı özel durumlarda tekrar yoğunluk kazanabilmektedir. Bireyin evlenmesi, çalışma hayatına atılması veya kırsaldan kente göç etmesi sosyalleşmenin özel ve yoğun yeni alan ve aşamalarının oluşmasına imkân sağlamaktadır.

Sosyalleşme, bilgi (information), tekrar (rehearsal), ötekilerin tepkileri (reaction of others) ve sosyal destekler (social supports) ile işleyen bir süreçtir. Bu süreç farklı aşamalara ve alanlara sahiptir. Konuyla ilgilenen bilim insanları farklı sosyalleşme aşamalarından ve çeşitlerinden bahsetmişlerdir. Bunlar içerisinde en yaygın kabul göreni sosyolog Charles Horton Cooley tarafından gerçekleștirilen ve sosyalleşme sürecinde egemen olan ilişkinin niteliğini esas alan sınıflandırmadır (Ritzer, 2011, s. 201-202; Coser, 2011, s. 275). Cooley'in sınıflandırmasıyla sosyalleşmenin iki ayrı aşamasından söz etmek mümkündür. Bunlar; 'birincil sosyalleşme', 'ikincil sosyalleşmedir'. Ancak diğer bazı bilim insanları tarafından literatüre kazandırılmış 'yeniden sosyalleşme', 'tersine sosyalleşme', 'beklentisel sosyalleşme', 'gelişimsel sosyalleșme' aşamalarından da bahsedilmiştir. Bunlar 'ikincil sosyalleşme' kapsamında yer alan alt düzey ve özel durumlarla ilgili sosyalleşmelerdir. Yine ayrı şekilde literatürde yaygın olarak yer alan 'kültürel sosyalleşme', 'dini sosyalleşme' ve 'siyasal sosyalleşme'... türleri de yer almaktadır. 'Kültürel sosyalleșme' ağırlıklı olarak 'birincil sosyalleşme' kapsamında, 'Dini sosyalleşme' ve 'siyasal sosyalleşme' ise ağırlıklı olarak 'ikincil sosyalleşme' kapsamında yer alan özel sosyalleşme türleridir. 


\section{Birincil Sosyalleşme}

Birincil sosyalleşme, Cooley'in tanımlamasıyla birincil gruplarda gerçekleşen ve birincil ilişkilerin egemen olduğu bir sosyalleşme türüdür (Ritzer, 2011, s. 201-202; Coser, 2011, s. 275). Birincil ilişkiler samimiyet ve duygusal yakınlığa dayalıdır. İlișkinin tarafları arasında güçlü ve yoğun duygusal bağ vardır. Bu bağlar kişisel menfaati önler ve fedakârlığı gerektirir. İlişkinin tarafları birbirlerini yakından ve detaylı olarak bilirler. İlişkiler ağırlıklı olarak yüz yüze, doğrudan, olup, karşılıklı etkileşim son derece güçlüdür. İlişkilerin şekillenmesini sağlayan kurallar ve ölçüler geleneğe dayanır. Birincil ilişkilerin şekillendirdiği gruplarda bireyler kendilerini grupla özdeşleștirmişlerdir. $\mathrm{Bu}$ sebeple grup aidiyeti bireysel varoluşun öncesinde yer alır; birey kendisini grubuna referansla tanımlar. Birincil ilişkilerin egemen olduğu birincil grupların en temel ve önemli örneği aile kurumudur. Çocukluk arkadaşlığı, mahalle ve köy yaşamı, akrabalık ilişkileri de birincil ilişkilerin baskın olduğu sosyal birimler olarak anlam kazanmaktadır.

Birincil ilişkilerin egemen olduğu en temel ve önemli sosyal birim olan aile, birincil sosyalleşme açısından son derece önemlidir. Zira birincil sosyalleşme, bireyin toplumla ilk kez karşı karşıya geldiği ve toplumla olan ilişkilerinin ilk ve temel özelliklerinin gerçekleştiği aşamayı ifade etmektedir. $\mathrm{Bu}$ aşama hemen her zaman aile kurumu içerisinde ve ağırlıklı olarak ebeveyn-çocuk ilişkileri bağlamında oluşup gelişir. Çocuk, kişiliğinin temel özelliklerini yaşamının ilk birkaç yılı içinde ve aile ortamında elde eder. Çocuk, konuşmayı, duygusal paylaşımı ve toplumsal dünyaya dair olanları ilk defa aile içinde öğrenmeye başlar. Çocukların öğrenme şekli benzerdir; fakat aileden aileye öğrendikleri şeyler değişir. Çünkü aileler, gelecekte çocuklarından değişik beklentiler içinde oldukları için birbirinden farklı değerleri öğretirler. İnsanın sosyalleşmesinde en önemli unsurlardan biri olan dil de ailede öğrenilir. Aile, ferdin, toplumla olumlu bir şekilde uyum sağlamasında önemli bir öğretim fonksiyonu ifa etmektedir. Topluma ait kıymet hükümleri, hayat görüşleri, örfler ve adetler ancak aile aracılığıyla ferde intikal edebilir. Toplumda hâkim olan 'iyi' 'kötü', 'doğru' yanlış' telakkileri de aile süzgecinden geçerek ferdin idrakine ulaşabilmektedir. Böylece aile çocuğun sosyalleşme sürecinde ilk ve en önemli işlevleri ifa etmektedir.

İnsan tutum ve davranışlarının çoğunluğu öğrenilmeyle edinilmiş özelliklerdir. Bunlar ise sosyalleşme sürecinde öğrenilmektedir. Temel insani tutum ve davranışların edinilmemesi veya bir başka ifadeyle özellikle birincil düzey sosyalleşmenin gerçekleşmemesi durumunda bireyin fizyolojik açıdan yaşaması zorlaşacağı gibi, kişiliğiyle de eksik, problemli bir varlığa dönüşür. Toplumsal değerleri içselleştirmeyen birey, normsuzluk ve yabancılaşma davranışlarını göstermektedir (Sezal, 2003, s. 268). Ayrıca kişiliğini sağlıklı bir yönde geliștiremeyen birey de, bireysel açıdan; mutsuz, kendine güveni olmayan, a-sosyal, kendine yetmeyen, ihtiyaçlarını karşılayamayan, problemlerini çözemeyen bir üye olacaktır (Ergenç, 2011, s. 48). Çünkü sosyalleşme, yukarıda ifade edildiği üzere, sadece toplumun üyesi olma süreci değil, aynı zamanda ve hatta daha fazlasıyla fizyolojik açıdan insan doğan bireyin, gerçek manada insanlaşmasıyla da ilgilidir. Zira evrensel insan yoktur; her birey toplumuna göre; toplumunda kazandığı ve o toplum bağlamında olması gereken özellikleri kazandığı oranda 'insan'dır. Bu durum Emilio Willems (1905-1997)'in sözlügünde şöyle karşılık bulmuştur: 'Bireyin yalnızca biyolojik bir varlık olmaktan çıkıp belli bir topluma ve belli kümelere bütünleștirilmesi sürecine sosyalleşme süreci denir. Bu süreç aracılığıyla birey kimlik ve kişilik kazanır. Böylelikle belli bir toplumda yaşamasını mümkün kılan özellikleri kazanır' (Willems, 1961). 
Birincil düzey sosyalleşme gerçekleşmediği zaman birey salt fizyolojik açıdan insan kalmakta, doğuştan getirdiği insani özellikler köreldiği için yeterince 'insanlaşamamaktadır'. İkincil düzey ve diğer sosyalleşmeler gerçekleşmediği zaman da birey genel anlamda toplumdaki diğer bireylerle veya grubuyla ve grup üyeleriyle önemli sorunlar yaşamakta, yaşam tarzına belirli bir düzen vermek mümkün olmamaktadır. Birincil düzey sosyalleşme gerçekleşmediğinde bireyin gelişim durumunun nasıl seyrettiği ve nasıl sonuçlandığıyla ilgili ilk ve kapsamlı araştırmalardan birisi Kingsley Davis (19081997)'e aittir. 'Final Note on a Case of Extreme Isolation' (1945) isimli makalesinde, sosyalleşmeyi sağlayan ortam, şart ve imkanların olmaması durumunu 'aşırı izolasyon' olarak niteleyen Davis, aşırı izolasyonun; bir diğer ifadeyle sosyalleşmeme durumunun seyri ve sonucu ile ilgili iki önemli örnek olay üzerinde çalışmıştır. Örneklerinden birisi Anna isimli çocuktur. Anna yaşamının ilk altı yılını karanlık bir odada ve dolayısıyla her türlü sosyal ortamdan ve ilişkilerden yalıtılmış bir halde geçirmiştir. Bu süre içerisinde sadece beslenme ihtiyacını karşılamak için arada bir yanına gelen zekâ özürlü annesi ile karşılașmıștır. Annesi onu ne kucağına alıp sevmiş ne de bir șey öğretmiştir. Anna, altı yaşına geldiğinde insan olmaya ilişkin hemen hiçbir şey görmemiştir. Anna, bulunduğu zaman yürüyemiyor ve konuşamıyordu. Sürekli tedirgin ve çevresine kayıtsızdı. Üstelik herhangi bir şekilde de olsa zekâ belirtisi göstermiyordu. Anna bulunduktan sonra psikolog ve pedagoglar tarafından incelemeye alındı. İki yıl süren tedavi, eğitme ve öğretme programları sonrasında sadece beslenmeyi, tuvalet ihtiyacını karşılamayı, yürümeyi ve bazı basit komutların gereğini yerine getirmeyi öğrenebildi. Tüm yoğun ve sistematik eğitim-öğretim çabalarına rağmen iki yaşındaki çocuğun düzeyini aşamadı. Bir süre sonra öldüğü için sürecin nasıl ilerleyeceğini bilme imkânı olmadı. Örneğin Anna'nın doğuştan mı zekâ geriliğine sahip olduğu, yoksa hayatının ilk altı yılını zekâ geriliğine sahip bir annenin yanında geçirdiği için mi zekâsının açılım kazanamadığı anlaşılamadı.

Kingsley Davis'in sosyalleșememenin seyri ve sonucu ile ilgili incelediği ikinci önemli örnek Isabella isimli çocuktur. Isabella gayri meşru ilişkinin ürünü olan bir çocuktu ve annesi tarafından insanlardan gizlenerek bir odada tek başına büyütülmüştü. Bulunduğu zaman altı yaşındaydı. Ürkek ve insanlar karşısında saldırgan davranışlar sergiliyor, tuhaf ve çirkin sesler çıkarıyordu. Isabella, Anna gibi yürüyemiyor, konuşamıyordu. Ayrıca annesi gibi sağır ve dilsizdi. Fakat sınırlı da olsa annesi ile el-kol hareketleri üzerinden bir ilişkisi olmuştu. Isabella eğitimcilerden oluşan profesyonel bir ekip tarafından eğitime tabi tutuldu. Isabella hızlı bir gelişim kaydetti. İki yıl içinde yaşıtlarıyla aynı düzeye erişti. Dokuz yaşına geldiğinde yaşıtlarıyla birlikte okul hayatına başladı. 14 yaşına geldiğinde 6 . Sınıf öğrencisiydi ve gelişim evresinde kayda değer bir eksiklik veya kusur görünmüyordu. Anna ile Isabella'nın gelişim sürecindeki farklılığın sebebi Anna'nın Isabelle kadar belirli bir potansiyele sahip bebeklik dönemi geçirmemesine ve öteki insanlarla daha az ilişki kurmasına bağlanmıştır. Buna karşılık Isabella sınırlı ve sığ da olsa annesi üzerinden bir ilişkiler sisteminin parçası olma imkânına sahip olmuştu (Elkin, 1995, s. 10).

Konuyla ilgili olmak üzere literatürde önemli yere sahip bir diğer örnek ise 1970'li yıllarda Kaliforniya'da bulunan 13 yaşındaki Genie'dir (Curtiss, 1977). 20 aylıkken sosyal açıdan yalıtılan ve tüm toplamsal ortamlardan ve ilişkilerden uzaklaștırılan Genie, bir odada, son derece minimize edilmiş ilişkiler içerisinde 13 yaşına kadar kalmış bir çocuktu. Genie, tüm çaba ve çalışmalara rağmen sosyalleșememiştir. Konuşma yeteneği 4 yaşındaki çocuğun konuşma seviyesini geçememiştir. Genie örneği ise sosyalleşme ile yaş arasındaki ilişkiyi göstermesi açısından özel ve önemli bir örnektir. Geç kalmış sosyalleşme sürecinin çok 
dar ve kısıtlı işlediği anlaşılmıştır. Bu durumdaki bireye ne tür eğitim verilirse verilsin, gelişim oldukça sınırlı kalmaktadır.

Anna ve Isabella örneklerinden anlaşıldığı üzere, sosyalleşmenin gerçekleşmemesi, kalıtım yoluyla geçen özellik ve yeteneklerin ya körelmesine ya da gerilemesine yol açmaktadır. Dolasıyla kalıtımla gelen özellik ve yeteneklerinde açığa çıkmasının ve işlevsel hale gelmesinin sosyal çevre ve sosyal ilişkilerle mümkün olduğu anlaşılmıştır.

\section{İkincil Sosyalleşme}

İkincil sosyalleşme, Cooley'in tanımlamasıyla ikincil gruplarda gerçekleșen ve ikincil ilişkilerin egemen olduğu sosyalleşme türüdür. İkincil ilişkiler kişisel değildir. İlişki yazılı kurallara dayalıdır. Bireyler kendilerini özne olarak algılar ve önceliği grup üyeliğine değil, özne birey olarak kendisine verir. İlişkilerde kişisel menfaatler baskın olup, bireyler arasında duygusal değil, rasyonel bağ baskındır. Birey ikincil grup üyeliğine isteyerek dâhil olur ve dâhil olurken beklentileri vardır. Birey istediği zaman; beklentileri gerçekleştiği veya gerçekleşmediği için kolaylıkla grup üyeliğini sonlandırabilir. Grubun üyeleri, birbirlerini yakından ve detaylı olarak tanımak durumunda değildirler. İkincil ilişkilerin egemen olduğu ikincil grupların en temel ve önemli örnekleri işyeri, siyasal parti, sendika, dernek, kent gibi yapı ve ortamlardır.

İkincil ilişkilerin egemen olduğu yapılarda gerçekleşen etkileşim ve iletişim ikincil sosyalleşme açısından son derece önemlidir. İkincil sosyalleşme büyük çoğunlukla çocukluk döneminde gerçekleșen birincil sosyalleşmeyi takiben bireyin yaşamının ileri yıllarında ve ölünceye kadar takip eden sosyalleşme aşamasıdır. Bu sosyalleşme sürecinde birey genel olarak toplumun özel olarak da daha küçük ve özel grupların üyesi durumundadır. İkincil sosyalleşmenin bazı alt türevleri vardır; 'yeniden sosyalleşme', 'tersine sosyalleşme', 'siyasal sosyalleșme'... gibi. Literatürde önemli bir yere sahip olan 'yeniden sosyalleşme', bireyin yaşamında gerçekleşen önemli değişmelerle ilgilidir. Örneğin kırsaldan kente veya kentten kırsala göç eden, evlenen, çalışma hayatına atılan, cezaevine giren, madde bağımlılığı olan ve bundan kurtulmak için tedavi gören, din değiștiren... bireylerin yeni durumlarına adaptasyonları yeni bir sosyalleşme sürecini gerektirir. Bu tür sosyalleșme yeniden sosyalleşme olarak isimlendirilmektedir. 'Tersine sosyalleşme' daha önce sosyalleşmiş bireylerden veya mevcut toplumsal çevreden etkilenmesi yerine onları etkilemesi ve değiştirmesi biçiminde gerçekleşen sürecin ismidir. Özellikle teknolojik gelişmeler tersine sosyalleşmeyi artırmıştır. Normal şartlarda çocuk veya genç, yaşça büyük olanlardan bir şeyler öğrenerek sosyalleşirken, teknolojik gelişmelere bağlı olarak çocuklar ve gençler yaşça büyük bireyleri etkileyerek onların yeni duruma uygun bir şekilde sosyalleşmelerini sağlamaktadırlar. Bugün itibarıyla tersine sosyalleşmenin en yoğun yaşandığı alan dijital teknoloji ile ilişkilidir. Bireyin mensubu olmadığı, fakat mensubu olmak istediği bir sosyal grubun değer, dünya görüşü ve davranışlarını benimsemesi 'beklentisel sosyalleşme'yi oluşturmaktadır. 'Beklentisel sosyalleşme' ile 'yeniden sosyalleşme' arasında yakın ilişki vardır. 'Gelişimsel sosyalleşme' ise her ne kadar tüm sosyalleșme aşamalarıyla irtibatlı olsa da daha çok bir kurum veya kuruluş içerisinde bireyin davranışların gelişim aşamalarını ifade etmektedir. Gelişimsel sosyalleşme en açık biçimiyle kariyer aşamalarına sahip kuruluşlarda gözlenmektedir. Birey her yeni hiyerarşik konumdan yeni bir sosyalleşme sürecine dâhil olmaktadır. 'Siyasal sosyalleşme' ise bireyin siyasal ölçütleri öğrenmesi ve siyasal tutum ve davranışlar edinmesiyle ilgilidir. Bu bir siyasal parti üyeliği üzerinden gerçekleşebileceği gibi, siyasal durum ve davranışları gözlemleyerek de gerçekleşebilir. 


\section{Geleneksel Medya ve Sosyalleşme}

Geleneksel medya, gazete, dergi, radyo, televizyon gibi iletişimin tek taraflı işlediği iletişim araçlarının genel ismidir. Geleneksel medyada iletişim karşılıklı değildir; ileti, iletişim araçları üzerinden hedefe doğru akar, hedeften kaynağa yönelik herhangi bir dönüş söz konusu olmaz. Geleneksel medyanın işleyişinde egemen olan anlayışa göre iletinin hedefi olan bireyler 'tüketici' durumundadırlar. Tüketici konumunda olmak iletinin alıcısı durumundaki bireyler tarafından da kabul edilmiştir; bunlar kendilerine verilen içeriği kabul eder, içerik üzerinde bir değişiklik yap(a)mazlar. Tüm bunların yanı sıra, geleneksel medyada, yayınlanan içeriğin veya gerçekleştirilen reklam ve duyuruların kimlere ulaştığı tam olarak bilinemez. Gerçekleştirilen çalışmaların sonuçlarını ölçmek, sonuçlarını değerlendirmek tam olarak mümkün olmaz.

Eğer sözlü iletişim dikkate alınırsa, iletişim insanlık tarihinin çok büyük bir kısmında ve çok büyük oranda kişiler arasında gerçekleşmiştir. Ancak bilimsel ve teknolojik gelişmeye bağlı olarak hem yeni iletişim teknolojileri icat edilmiş ve hem de bu teknolojilerin etki gücü çok hızlı bir şekilde büyümüştür. Böylelikle bir iletişim aracı üzerinden çok büyük kitlelere ulaşmak mümkün hale gelmiştir. Bu büyümede radyo önemli bir eşik olmakla birlikte, televizyon çok ileri düzey bir iletişim aracı olarak işlev görmüştür. Örneğin televizyon üzerinden aynı anda yüz milyonlarca ve hatta milyarlarca insana ulaşmak mümkün hale gelmiştir. Milyarlarca insan aynı programı izleyerek aynı iletilere maruz kalabilmektedirler. $\mathrm{Bu}$, yüzyıl öncesi bile hayal ötesi bir durumu ifade etmektedir. McLuhan (1911-1980)'ın tespit ve görüşüyle ifade etmek gerekirse; ilk geleneksel medya aracı matbaadır (McLuhan, 2011,s. 320). Matbaa sayesinde on binlerce, yüz binlerce insana aynı mesajı iletmek mümkün olmuştur. Ancak bu iletişim tekniğinde her bireyin belirli düzeyde özne olduğu ve o iletiye muhatap olması için okumak gibi emek isteyen bir çabaya girmesi gerektiği açıktır. Dolayısıyla matbaanın geleneksel kitle iletişim araçları arasındaki rolü, radyo ve televizyon gibi sonraki kitle iletişim araçları ile karşılaştırıldığında daha farklı işlemiş, etkisi daha sınırlı olmuştur. 1920’lerde hayata giren radyo belki de kitlesel olarak halka yayılmış ilk önemli kitle iletişim aracıdır. Radyo ile basılı kültür döneminin ön plana çıkardığı gözün yerini yeniden kulak almıştır. Bilindiği üzere kulak, sözlü iletişim döneminin en önemli iletişim aracıdır. Radyo 1930'larla 1940’larda altın çağını yaşadı. Çok kısa bir dönem içinde son derece etkili bir iletişim aracı oldu. İletişim tarihçisi Walter J. Ong (1912-2003)'a göre (2018, s. 160) 'elektronik medya kültürü' de denen ve radyoyu, televizyonu ifade eden iletişim araçları, hem iletişimin yazıyla başlayıp matbaayla pekiştirilen mekân bağlarını dönüştürmüş, hem de insan bilincini ikincil sözlü kültür çağına sokmuştur. Geleneksel medya, okuma yazma kurallarını, eğlenmenin zaman ve özelliklerini değiştirmiş, duyuları yeniden biçimlendirmiştir.

İkinci Dünya Savaşı yıllarında iletişim tekniklerinin en önemli temsilcisi ve kitle iletişiminin zirvesi olan radyo gittikçe azalan bir ivmeyle insanların sosyalleşmesinde önemli roller üstlendi. Büyük oranda ikincil sosyalleşmenin, daha çok da siyasal sosyalleşmenin en önemli aracı oldu. Radyonun iletişimdeki açı ara liderliği televizyon ile bitti. Televizyon hem iletişim teknikleri ve hem de bireylerin sosyalleşme biçim ve süreçleri açısından radikal değişimi ifade etmektedir. Çünkü hem göze, hem de kulağa hitap etmektedir. İki ayrı duyu organı üzerinden iletisini aktarıyor olması, iletisini aktarım ve kabulünde ikna gücü açısından televizyonun geçmişteki tüm iletişim araçlarına göre son derece ayrıcalıklı bir yere sahip olmasını sağlamıştır. Televizyon, Sanayi Devrimi sonrasında oluşan ve bireylerin tüm tutum ve davranışlarında, duygu ve anlayışlarında 
etki gücünü gittikçe artıran 'serbest zaman' kurumunun önemli bir temsilcisi olarak işlev görmüș, bu yönüyle hem eğlence aracı, hem de bilgi edinme aracı olmuştur. Televizyon bilhassa çocukların bakıcısı haline gelmiş ve birçok şey televizyondan öğrenilmeye başlanmıştır. Çocuk, ekrandan kendisine sunulan bir dünyayı kucaklamıştır. İkincil sosyalleşmenin rakipsiz lideri olduğu gibi, birincil sosyalleşmede de aile ile yarıșmıştır. Hatta birincil sosyalleşmede etki gücü açısından aileyi geçtiği, ailenin etki gücünün televizyon karşısında oldukça sınırlı hale geldiği bile dillendirilmiştir (Rigel, 1994, s.12; Yavuzer, 1986, s. 80).

Geleneksel medya araçlarının çeşitlilikleri, yaygınlıkları ve iletişim alanına getirdikleri yeniliklerle ikincil sosyalleşmede daha çok olmak üzere, her sosyalleşmenin her iki aşamasında da güçlü bir etkiye sahip oldular. Her yaștan herkes geleneksel kitle iletişim araçlarının etkisi altında yer aldı. Televizyon ise tüm diğer geleneksel iletişim araçlarının toplam etkisi aşan bir güce sahip oldu. Kültürel, dini ve siyasi sosyalleşmede televizyonunu ayrıcalıklı bir konumu oldu. Bu etki televizyon izleme süresinin uzunluğunda kolaylıkla anlaşılabilir. Türkiye'yi örnek olarak dikkate almak gerekirse; evreni Türkiye olan 2011 tarihli bir araştırmada (Sekam, 2011, s. 220) 18 yaş ve üzeri kesimin günlük televizyon izleme süresi oldukça dikkat çekicidir. Araştırmanın katılımcılarının \%20,4'ü 6 saat ve üstü, \%33,7'lik bir kesim ise günde 3-6 saat süre ile televizyon izlediğini ifade etmiştir. Bir bașka araștırmanın bulgularına göre üniversite öğrencilerinin 20,5'i günde 3-4 saat televizyon izlemektedir (Toruk, 2008, s. 480). Kuşku yok ki bunlar oldukça yüksek oranı temsil etmektedir. Dolayısıyla geleneksel kitle iletişim araçları, bireylerin sosyalleştirme sürecinde, aile ve okulla yarışan ve hatta onları geçen bir etkiye sahip oldular. Özellikle bireylerin, kültürel, ekonomik, dini, siyasi tutum ve kanaatlerinin oluşmasında, tüketim eğilimlerinin seyri ve yoğunluğunda kitle iletişim araçlarının merkezi rol oynadığı bilinmektedir. Geleneksel medyanın bu etki gücü sadece bireylerin sosyalleşmelerinde açığa çıkmamış, tüm insanlığın genel gidişatında bir benzeşmeye yol açmıştır. Küreselleşme denen durum bunun sosyal bilimlerdeki teknik ismidir. Sosyolog Roland Robertson (d. 1938) yaşanan gelişmeleri 'dünyanın bir bütün olarak düşünülmesi' şeklinde tanımlamaktadır (Robertson, 1999, s. 49). Televizyon başta olmak üzere geleneksel medya araçlarının sayesinde taşınan değerler, semboller ve inanışların tüm engelleri delip geçtiğinden söz eden David Friedman (d. 1945)'a göre 'dünya düzleşmiştir'. Dünya yeni elektronik ağlarla duvarlarından arınarak düzleşmiştir; dijital, kablo ve çeşitli bağlantılarla birbirine bağlanmıştır (Friedman, 2006, s. 153). 1990’ların dünyasında 'Küresel Köy', 'Global İnsan' ve 'Bilgi Çağı' gibi isimlendirmeler sıkça vurgulanmış; insanlığın maruz kaldığı yeni durum sayısız denecek kadar çok araştırmanın konusu olmuştur. Bu arada iletişim literatürü yeni kavramlaştırmalarla karşılaşmıştır. 'Suskunluk sarmalı' bunların içerisinde oldukça önemlidir. 'Suskunluk sarmalı' (Spiral of Silence) geleneksel medyanın bir sonucudur. Geleneksel medyanın tek yönlü iletişim özelliğine bağı olarak belli başlı kimliklerin sosyal kabule sunulması ve toplumun tamamı tarafından onaylanmış kimlikler olarak lanse edilmesi 'suskunluk sarmalının' oluşum nedenidir. Çünkü bu durumda birey sunulan bu kimliklerle zit düşen görüşlere sahip olsa dahi, toplum tarafından dışlanmamak adına sessizliğe bürünmeyi tercih etmektedir. Kavramlaştırmanın öncüsü Alman sosyolog Elisabeth Noelle-Neumann (1916-2010)'dır. Noelle-Neumann'ın 'Suskunluk sarmalı' olarak isimlendirdiği durum, bireyin kendisine medya veya toplum tarafından sunulan veya dayatılan görüşlere, kimliklere, rollere; kendi görüşüyle çelişse dahi ayak uydurmaya çalıştığını vurgulamaktadır (Neumann, 1993). 


\section{Sosyal Medya ve Sosyalleşme}

İletişim teknolojilerinde radikal düzeyde olmak üzere gerçekleşen büyük değişimler 'elektronikten dijitale' olarak adlandırılan dönemde gerçekleşmiştir. Bu dönem 20. yüzyılın son çeyreğine denk düşmektedir. 20. yüzyılın son çeyreği ile birlikte iletişim alanında yeni bir döneme geçilmiş, süreç asıl etkilerini geçtiğimiz son 20 yıl içinde göstermiştir. $\mathrm{Bu}$ etkiler sebebiyle 2000 ve sonrasında doğanlar 'Z kuşağı', 'Milenyum kuşağı', 'Dijital yerliler' gibi önceki dönemlerde doğmuş olanlardan ayrıștıracak isimlerle anılmaktadırlar. Çünkü internet ve internet üzerinden gerçekleșen iletişim ve etkileșim bireyler açısından kişilikleriyle, yaşam tarzlarıyla, tutum ve davranışlarıyla tüm zamanlarınkinden çok başka bir kuşağın oluşmasına yol açmıştır.

Genel anlamda son 40-50 yıllık dönem içerisinde gerçekleşen; başta radyo, telgraf, telefon, televizyon olmak üzere 20. yüzyılın büyük çoğunluğunda egemen olan kitle iletişim araçlarının niteliğinde gerçekleşen değişimdir. $\mathrm{Bu}$ dönemde doğan ve gelişen internet teknolojisi, öncelik iletişimde olmak üzere bireylerin tüm yaşamlarını etkileyecek yeni şartların ve imkânların oluşmasına yol açtı. Ses, görüntü ve veri içeriklerini etkileşim öğesini de içerecek şekilde bir arada toplayan iletişim araçları (medya) bu yönüyle öncesinden ayrıldı. Bu ayrılış 'yeni medya' ve 'geleneksel medya' ayrımının oluşmasına yol açtı. Yeni iletişim kültürü uzun bir süre 'Yeni medya' olarak isimlendirilirken, artık 'Sosyal medya' olarak isimlendirilmektedir. Yeni/Sosyal medya, gelişen bilgisayar, internet ve mobil teknoloji ile ortaya çıkan, kullanıcıların zamandan ve mekândan bağımsız bir şekilde interaktif olarak etkileşimde bulundukları medya araçlarının genel ismidir. $\mathrm{Bu}$ medyanın ismindeki 'yeni', işleyiș tarzı tamamen farklı olan geleneksel olandan ayırmak için tercih edilmiştir. 'Yeni' olarak ifade edilen özellik mesajla değil, ortamla ilgilidir. $\mathrm{Bu}$ iletişim biçimini çoklu ortam (multimedia), etkileşimlilik (interactivity), yayılım, sanallık (virtuality), kitlesizleștirme, asenkron olabilme özellikleri, geleneksel medyadan ayrılmasına ve 'yeni' olarak nitelenmesine neden olmuștur. Kullanıcıların konumlarına bakılmaksızın, ulaşılabilir ve tüketilebilir nitelikte olan dijital iletişim ve bilgi kanalları yeni medya olarak tanımlanmaktadır (Hennig, 2010, s. 312).

Sosyal medya, şu ana kadarki tüm iletişim araçlarına oranla en yüksek derecede görüntülü, yazılı, sesli bilgi, belge paylaşımının gerçekleştiği bir iletişim mecrası olarak anlam kazanmaktadır. Online nitelikte bir iletișim mecrasıdır. Mayfield'in tespitleriyle ifade etmek gerekirse, sosyal medya iletişimi şu özellikleri açısından diğer iletişim araçlarından ve mecralarından ayrılmaktadır (Mayfield, 2010): Katılımcılar açısından: Sosyal medya katılımcılara cesaret veren, bilen-bilmeyen ayrımının sıfırlandığı, bilgi ve tecrübe konusunda hiyerarşik ayrıșmanın düzleștiği bir mecradır. Üstelik sürece dâhil olan her bir kullanıcıdan geri bildirim alır. Açıklık açısından: İletişim araçlarında belirli düzeyde de olsa açıklık durumu vardır. Ancak hiç biri sosyal medyadaki ile aynı düzeyde değildi. Mevcut iletişim araç ve mecraları içerisinde en çok sosyal medya servisleri geribildirime ve katılımcılara açıtır. Bu servisler oylama, yorum ve bilgi paylaşımı gibi konularda katılımcılara yüksek oranlarda cesaret aşılarlar. Bunlar çok nadir ulaşıma yönelik engeller koyarlar. Konuşma açısından: Geleneksel medya içerik aktarımı ya da dinleyiciye bilgi ulaşımı açısından yayına ilişkin iken, sosyal medya iki yönlü konuşmaya imkân tanıması bakımından çok daha olanaklı durumdadır. Toplum açısından: Sosyal medya topluluklara çabuk ve etkili bir iletişim ve paylaşım için izin verir; teşvikte bulunur. Bireyler de beğendikleri fotoğraf, politik değerler, favori TV şovları gibi ilgili oldukları konuları, görüntüleri bilgileri paylaşırlar. Bağlantılılık açısından: Sosyal medya 
mecralarının çoğu, bir ağ sisteminin parçası durumundadırlar. Diğer siteler, araştırmalar ve insanların ilgili oldukları herhangi bir konuda link verilmesine imkân tanırlar.

Sosyal medyada etkileşim ve paylaşım merkezi bir konuma sahiptir. Bu özelliğe bağlı olarak dünyadaki fiziksel, sosyolojik ve ekonomik sınırlar değişime uğramış, yerelliğin ve küreselliğin eş anlı varlık gösterdiği yepyeni bir dünya inşa olunmuștur. Sosyal medyada içeriği bireyler oluştururlar. Bu özelliği bağlamında sosyal medya nedeniyle geleneksel medyanın kitleleri yöneten ve yönlendiren yapısı radikal düzeyde değişime uğramış, izleyici tüketici olmaktan çıkıp üre-tüketici (prosumer) olmaya başlamıştır (Laughey, 2010, s. 66, 67). Prosumer sözcüğü, 'producer' (üretici) ile 'consumer' (tüketici) sözcüklerinin birleşiminden oluşmakta ve kullanıcının medya üzerindeki etkinliğinin arttığını ifade etmektedir. Diğer bir ifadeyle, izleyici/kullanıcı sosyal medya ile üretici/ anlam yaratan konumuna ulaşmıștır.

Bir bütün olarak göz önünde bulundurulduğunda iletişim sürecinde 'kaynak', 'hedef', 'ileti', 'kanal', 'gürültü' ve 'geri bildirim' unsurları vardır. Geleneksel iletişim teknolojisini insanlığın en uzun süre kullandığı ve kullanmaya devam ettiği sözlü iletişimden ve internet teknolojisi ile oluşan iletişim süreçlerinden ayıran en belirgin özellik, geri bildirim özelliğinin olmaması ya da son derece sınırlı olmasıdır. Örneğin radyo ve televizyon izleyicinin müdahalesine izin vermez. Bu aşamada Sennet'i dinlemek gerekirse, geleneksel medya geçen yüzyılda tiyatrolarda ve konser salonlarında biçimlenmeye başlayan kalabalık halinde sessiz kalma tarzlarını pekiştirmiştir (Sennett, 2013, s. 364, 365). İletiye maruz kalan kitleler, bu iletiyi isteyerek veya istemeyerek de olsa aldılar ve eğer varsa tepki verme imkânına sahip olmadılar. Tepkisizlik genel bir kabul durumu olarak anlam kazandı. Ancak günümüzde internet teknolojilerinin iletişim sürecinde ortaya çıkardığı yeni unsurlardan biri olan sosyal medya bireylerin eşzamanlı olarak birden fazla ve 'karşılıklı' iletişimi sürdürmelerine imkân sağlamaktadır. Buradaki karşılıklı olma durumu, özel bir anlam ifade etmekte olup, ileri sayfalarda daha detaylı olarak konu edinilecektir. Dolayısıyla birey, 'karşılıklı' iletişim kurduğu bireylerden biri ile aynı uzam ve zamanı paylaşırken, makine ile gerçekleşen iletişim sayesinde iletişim halinde olduğu birey ile farklı gerçek uzamı, aynı zamanı ve aynı siber uzamı paylaşmaktadır. Bilgisayar ve telekomünikasyon ağları, tüm dünyayı kuşatan yeni ve yapay bir iletişim atmosferi oluşturmuştur. Bilgisayar teknolojisi, gazete, dergi, radyo hatta televizyon gibi geleneksel iletişim araçlarının okuyucularının, dinleyicilerinin ve izleyicilerinin tahmin edemeyecekleri ölçüde iletişim dünyasını değişime uğratmış, günümüzde kişiler artık telematik ve videomatik araçlarla kuşatılmakta, görüntülü kitapları, online gazeteleri okumakta, kağıdın yer almadığı ofislerde çalışmakta, dünyanın bir ucundaki ülkelerde olup biteni canlı olarak uydu yayınlarıyla izleyebilmektedirler (Uluç, 2003, s. 14-15).

İnternet teknolojisinin icadı ve gelişmesi ile gündelik hayatın ayrılmaz bir parçası haline gelen sosyal medya, sosyalleşme süreçlerinde ve dolayısıyla gündelik yaşam pratiklerinde önemli bir dönüşümü başlatmıştır. Bu dönüşüm ve değişimde sosyal medyanın diğer tüm iletişim araç ve ortamlarından farklı özelliklere sahip olması vardır. Sosyal medya, basit ve genel bir nitelemeyle, internet üzerinden kişiler arası konuşma ve iletişime imkân sağlayan bir ortamdır. Bireylerin internette birbirleriyle yaptıkları iletişimler ve paylaşımlar sosyal medyayı oluşturmaktadır. Bu medyada ulaşım, bir kişiden yüzlerce kişiye, yüzlerce kişiden de yüzbinlerce, milyonlarca kişiye biçiminde işlemektedir.

Genel manada internet, özel olarak da sosyal medya insanların temel alışkanlıklarında radikal değişimlere yol açmıştır. Örneğin öğrenciler için ödev hazırlamak kütüphaneye 
gitmek, kitap, ansiklopedi incelemek anlamlarından ayrılmıştır. Artık kütüphane gezip kitap tarama, kitaplık önünde zaman geçirme alışkanlığının yerini e-book’ları incelemek, forumlara bakmak almıştır. Onlarca, yüzlerce fotoğrafın titiz bir şekilde yerleştirildiği fotoğraf albümleri evlerdeki özel yerlerinden, özel değere sahip kişilerin fotoğrafları cüzdanların başköșesinden buharlaşıp gitmiş, fotoğraf albümlerinin yerini sürekli yeni fotoğrafların eklendiği sosyal medya hesaplarındaki sanal albümler veya özel fotoğraflar mobil telefonların, tabletlerin bilgisayarların ekranını süslemeye başlamıștır. Doktorların tıp alanındaki en büyük rakibi forumlardaki 'hekimler', eğitimcilerin en güçlü rakipleri sosyal medya mecralarındaki 'uzmanlar' olmaya başlamıştır. Bir ileti binlerce geri bildirim ile iletişimi başlatanın başta düşündügü ve hedeflediğinden daha farklı kulvarlara evrilebilmekte; çok kolaylıkla kaynak hedefe, hedef kaynağa dönüşebilmektedir. Gerçek buluşmaların, duyguların eșlik ettiği yüz yüze sohbetlerin yerini chatleşmeler almıştır. Ve tüm bunlar sosyalleşmek olarak isimlendirilmektedir.

İnternet teknolojisinin önemli unsurlarından birisi olan sosyal paylaşım siteleri, herkesin ulaşabileceği kişisel profil oluşturmayı ve kullanıcılar arasında iletişimi mümkün kılan online iletişim araçlarıdır. Sosyal paylaşım siteleri fotoğraf, müzik, film, video, kitap paylaşımına; kültürel etkinliklere katılıma; görüş, düşünce ve inançları dillendirmeye; farklı felsefe, anlayış ve inançları dillendirmeye, tartışmaya ve paylaşmaya; arkadaşlıklar kurmaya imkan sağlayan online ağlardır. Bu ağlarda bireyler yeni dostluklar kurabilmekte, eski veya yeni tanışlar birbirleriyle irtibata geçebilmekte, ilgili oldukları konu ve durumlara ilişkin içerik paylaşımında bulunabilmekte, sohbet ortamları oluşturabilmekte ve tüm bunların üstünde kendilerini bir sosyal çevrenin üyesi kılmakta veya mevcut üyeliği kolaylıkla sona erdirebilmektedirler.

Sosyal ağlar, bireylere, genel ya da yarı genel profil oluşturmaya, iletiyi paylaşan diğer kullanıcıların listesindekilerle konuşmaya, onların bağlantı listelerine bakmaya, oradan çapraz geçişler yapmaya ve de sistem içindeki diğer bireylerin de bunları yapmasına imkan veren web tabanlı hizmetlerdir. Sosyal ağlar, bireylere istedikleri bilgi ve görüşün, fotoğraf veya videonun son derece hızlı bir şekilde ve çok küçük maliyetlerle milyonlarca kişiye ulașmasına imkân sağlamaktadır. Özel ve genel, yerel ile küresel, bireysel ve toplumsal iç içe girmiştir. Bu kategorilerin arasındaki sınırlar sanallaşmış, sınırlar buharlaşıp kaybolmuştur. Bireysel ve toplumsal alışkanlıkla ve kabuller radikal denebilecek düzeyde değişime uğramış ve uğramaya da devam etmektedir. Örneğin mahremiyet algısı bu değişimin en önemli nesnelerinden birisi olmuştur. Geleneksel anlayıșta ve internet teknoloji öncesinde titizlikle korunan özel alanın kapısı, internet teknolojisinin sunduğu imkânlarla bizzat bireyin kendisi tarafından ve isteyerek tandık ve tanımadık herkese açılmıştır. Daha doğrusu özel alanın sadece kapısı açılmamış, tüm duvarları yıkılıp her şey ayan-beyan herkesin önüne konulmaya başlanmıştır. Artık bireyin ne zaman canının sıkıldığını, akşam yemeğinde ne yediğini, flörtü ile ilişkisinin nasıl gittiğini, ne yaptığını ve ne yapmak istediğini sadece arkadaşları, tanıdıkları değil herkes bilir hale gelmiştir. Önceleri mekâna ve iletişimin sınırlı imkânlarına bağlı olarak mevcut dostluklar sürdürülür, zaman ve mekânın değişmesi ile çok geçmişlerde veya en derin hatıralarda kalan dostlara ulaşma imkânları sınırlı olduğu için onlarla ilgili hatıraları hatırlamakla yetinilirdi. Fakat internet teknolojisi bunu da değiștirdi. Bireylere dostlukları sonsuz büyüklükteki mekânın ulaşılamayan bir köşesinde ve derin zamanın geçmiş bir anında kalmış olan dostlara ulaşma imkânı sunabilmektedir. Hem de çok hızlı ve sıfır maliyetle. Bugün herkes interneti sunduğu imkânlarla eski arkadaşlarını bulabilmekte, onlarla iletişime geçebilmekte, dostluklarını yenileyebilmektedir. 
Sosyal medyada son trend Facebook, Twitter vb. gibi, sosyal ağ siteleridir. Sosyal medya, yaygın bir șekilde kullanılan ve hatta bu ağlara dâhil olmamanın eksiklik olarak algılandığı, tuhaf karşılandığı bu günün dünyasında söz konusu ağ siteleri en yaygın ve en yoğun kullanılan iletişim ortamlarıdırlar. Bu iletişim mecraları, günlük yaşamda iletişim kurmakta zorlanan bireylere, kolaylıkla iletişim ve birçok kişiyle tanışma imkânı sunmaktadır. Gerçek ortamın iletişimi etkileyen, kısıtlayan utandırıcı, mahcup edici, çekindirici özellikleri sosyal ağ sitelerinin evreninde yok olmakta, bireyler herhangi bir duygusal, düşünsel, değersel sınırlama ile karşılaşmaksızın istediği kişilerle istediği şekilde iletişe geçebilmektedir. Bu sebepledir ki bireyler sosyal ağ sitelerinde kendilerini çok kolay şekilde ifade edebildikleri gibi, günlük yaşamda kendilerini ifade etmekte güçlük çekenler, utangaç ya da kendine yeterince güveni olmayan kişiler bile sanal ortamda kendileri ya da hayallerindeki kişi gibi olabilmektedirler.

İnternet aracılığıyla online topluluk olgusuyla karşılaşılmıştır. $\mathrm{Bu}$ olgunun oluşumunda önemli katkıya sahip olan sosyal ağ siteleri gittikçe yaygınlaşmış, neredeyse herkesin dâhil olduğu bir ortamı temsil eder olmuştur. Sosyal ağ siteleri iletişimin ve etkileşimin yeni ve farklı bir mecrası olarak anlam kazanmaktadır. Bireyler arasında gerçekleşen yüz-yüze iletişimin yerini almaya aday olacak kadar yaygın kullanılmaya başlanmıştır. Bireylerin sanal olarak bir araya gelerek görüşlerini, inançlarını paylaştıkları bu mecralar, bireysel gündelik hayatın en önemli unsurlarından birisi haline gelmiş bulunuyor. Bir araya gelinen mekân sanal olduğu gibi, kimliklerin sanal olma durumu da son derece yüksektir. Sanal olmayan kimlikler bile revize dilmiş kimliklerdir; kişi kimliğini titiz bir şekilde yeniden kurgulamaktadır. Fakat her şeye rağmen bu mecralar kimliklerin ve kişiliklerin oluşumunda son derece güçlü etkiye sahip hale gelmiş durumdadır. İnternet üzerinden yer alan bu sosyal ağlarda insanlar birbirlerine arkadaşlık teklifi yapmakta, arkadaşlar birbirlerinin duvarına yazmakta, posta kutularına mesaj bırakmakta ve etkinliklere katılım için davetiye göndermektedirler (Acun, 2011, s. 67).

\section{Sanal Sosyalleşme}

Detaylı olarak ifade edildiği üzere sosyalleşmenin birey ve toplum açısından yerine getirdiği farklı işlevler vardır. Birey sosyalleşme sayesinde insanî nitelikler kazanmakta, toplumunun normal bir üyesi haline gelmekte, yaşam tarzını şekillendirmekte, geçmişin deneyimlerinden yararlanarak zaman kaybı yaşamaktan kurtulmakta, farklı düzlemlerde söz konusu olabilecek risklerden uzak durmaktadır. Yine birey sosyalleşme sayesinde mevcut sosyal kümeye kolaylıkla dâhil olmakta, yeni dâhil olduğu sosyal üyeliklerin gerektirdiği ilişkiler evreninde güven kazanmakta, bilinmezliklerin yol açtığı korku ve tedirginlikleri kolaylıkla üzerinden atabilmektedir. İletişimin en temel aracı olan dili dahi sosyalleşme sürecinde edinmekte ve geliștirmektedir. Ayrıca iletişime kapsam ve derinlik katan jest, mimik, beden dili gibi unsurları sosyalleşme sürecinde öğrenip uygulamaya aktarmaktadır. Sosyalleşmenin toplum veya toplumsal kesim açısından işlevleri arasında en önemlisini ise, edinilen yeni üyeler aracılığıly topluma/toplumsal kesime süreklilik kazandırması ve toplumsal yapının işleyişine katkı sağlaması oluşturmaktadır.

Sosyallik ve sosyalleşme açısından sosyal medya dikkate alındığında, sosyal medyanın 'sosyallik' durumu, rutin dışı bir sosyalliktir. Sosyal medyanın sosyalliği ciddi tereddütleri gerektirecek, büyük sorular sormaya vesile olacak bir 'sosyalliktir'. Çünkü ilişki ve iletişim sınırlı, sığ ve çok daha önemlisi zaman ve mekândan büyük oranda kopmuş durumdadır. Sosyal medyada sınırlı bir 'iletişim'den bahsetmek mümkünse de 'ilişki'den bahsetmek çok zordur. Elbette ki haberleşme, bilgi aktarımı, sohbet etme, dertleşme, danışma gibi bireyler arası ilişkilerin gerektirdiği birçok şeyi gerçekleştirmek mümkündür. Fakat 
bunlar da son derece 'plastik' nitelik arz etmektedir. Üstelik kimliklerin gerçekliği ciddi kuşkuların sebebidir. Kimliklerin sanallık durumu söz konusudur. 'İletişim' halinde olunan kişinin gerçeklik düzeyi, kimlik ve kişilik özellikleri gerçek olmama ihtimali taşımaktadır. Cinsiyet, yaș, sosyo-ekonomik durum, medeni durum, etnik/ulusal kimlik gibi demografik niteliklerin bile gerçekliği konusunda kuşkuların bulunduğu bir kuşku atmosferinde gerçekleşen iletişimin işlevi doğal olarak sürecin geleceğine ilişkin beklentileri sorunlu hale getirebilmektedir. Aldanmanın, maddi ve manevi açıdan zarara uğratılmanın son derece kolay olduğu bir ortamda oluşturulan ve geliștirilen ilişkilerin, dostlukların anlamı sorunlu olduğu gibi, güven daha çok umudun bir unsuruna dönüşmektedir.

Sosyal medya, zaman ve mekânda olduğu kadar, kimliklerde de yapısal ve işlevsel değişikliklere neden olmuş, tüm bunları büyük oranda sanallaştırmış ve sosyal medyanın öznesi görünen bireyler zaman ve mekân sınırlaması olmadan bilgi ve duygu paylaşımı yapabilir hale gelmiștir. Sosyal medyanın aktörleri siber toplumun üyeleridirler ve sanal uzayda yaşamaktadırlar. İşlemekte olan zaman anlıktır. Bu zamanın öncesi ve sonrası yoktur. Sosyal medya sayesinde gerçeklik de sanallaşmış ve sosyal medya sanallaştırıcı gücü ile her şeyi nesnel gerçeklikten siber uzamın parçasına dönüştürmeye başlamıștır (Robins, 1999, s. 148, 154). Dolayısıyla sosyal medya bireyler arası ilişkilere bir katkı sağlasa da bu katkı kaliteli bir sosyalleşme olmaktan oldukça uzaktır. Sosyal medya aracılığıyla değişip dönüşen ilişkiler yen bir sosyalleşme anlayışının oluşmasına yol açmıştır. Fakat bu birçok bakımdan sanal nitelikte bir sosyalleşmedir. Bu sanal sosyalleşmenin aslında bir asosyalleşme süreci olduğu görüşlerinin yaygın olması tesadüf değildir. Bazı düşünür ve kuramcılar sosyal medyanın yarattığı bu yeni sosyalleşme algısını 'hareketsiz toplumsallaşma' olarak açıklamaktadırlar (Öztürk, 2013, s. 101).

Sosyal ağların ortaya çıkması ve yaygınlaşmaya başlamasının ardından oldukça radikal sayılabilecek bir değișim meydana geldi. Ontolojik ve epistemolojik 'gerçekliğin' temelini teşkil eden zaman ve mekân (uzam) değișime uğradı. Normal şartlarda ve dolayısıyla alışılagelmiş anlam ve işleviyle, Henri Lefebvre'in (1991, s.24) de dikkat çektiği üzere, zaman ve mekân birbirlerine eklemli olmasına karşılık, dijital sosyal ağlarda birbirlerinden koptukları gibi anlamsal ve işlevsel bir değişime de uğradılar. Giddens'ın da ifade ettiği üzere (1999, s.24) yakın zamana kadar 'ne zaman' sorusu 'nerede' sorusuyla ilişkiliyken, artık bu ilişki kopmuş bulunuyor. Gerçekleşen değişim, John Cairncross'a göre 'mesafenin ölümü' (Cairncross, 1997), Paul Virilio'ya göre ise 'coğrafyanın sonu' (Virilio, 2018) olarak anlam kazanmaktadır. Böylelikle yüz yüze iletişim giderek yerini çevrimiçi iletişime bırakmıştır (Toprak vd., 2012, s. 159). Yüz yüze iletişimin çevrimiçi iletişime yerini bırakması, ilişkilerin yüz yüze değil de bir aracılı cihaz (internet ve sosyal ağlar) vasıtasıyla gerçekleşmesini sağlamaktadır. Sohbet etmek için insanlar artık, yüz yüze iletişim yerine anlık mesajlaşma (Instant Messaging) uygulamalarını tercih etmektedirler (Toprak vd., 2012, s. 159).

Sosyal medya bireysel ve sosyal dünyaları birbirine bağlayarak, kişilerarası iletişimin ve kitle iletişiminin bir toplamını sunmaktadır (Van Dijk, 2018, s. 251). Bu toplamı Baudrillard'ın isimlendirmesine atıfla bir tür simülasyon olarak adlandırmak yanlış olmayacaktır. Van Dijk'e (2018, s. 256-257) göre, sosyal medyanın yükselişi öncesinde internette hangi becerilere sahip olabileceğini öğrenen internet kullanıcıları, sosyal medya dönemine gelindiğinde sosyalleşme ihtiyaçları ile dikkat çekmektedirler. Sosyal medyanın kullanım sıklığını ifade ederken Van Dijk (2018) şunu belirtmektedir: 'Pek çok kişi neredeyse takıntılı bir biçimde bazen gece ve kahvaltıdan önce Facebook ve Twitter sayfalarını kontrol etmektedir. Sonuçta sosyal medya faaliyetlerini takip etme yönünde 
bir baskı vardır' (s. 262). Sosyal medya ile yaşanmaya başlanan süreci Bauman 'mekânın değer kaybı' olarak nitelemektedir. Esasen insan bugüne kadar hiçbir şekilde tecrübe etmediği yeni bir mekân (siber mekân) ile karşı karşıya kalmıştır. Nowotny'nin (Nowotny, 1994) tanımlamasıyla söylemek gerekirse mekânsız eş zamanlılık keşfedilmiştir. İletişim teknolojilerinin gelişimi zaman ile uzamın birbirinden ayrılmasına ve aralarındaki sınırların erimesine sebebiyet vermiş, dolayısıyla modernitenin burada ve şimdi somutluluğunun tersine, artık özel bir bölgeye bağlı olmayan bir şimdi duygusu ortaya çıkmıştır (Thompson, 2008, s. 57). Bu sayede geçmiş, şimdi ve geleceğin, aynı mesaj içerisinde etkileșime girmesiyle meydana gelen akışlar uzamı ya da zamansız zaman (Castells, 2008: 501) yeni bir sanallık kültürünü ortaya çıkarmıştır. Bu bağlamda Aharon Kellerman'a kulak vermek gerekirse, sanallık aslında offline/fiziki dünyada insan eliyle yapılmış tablo gibi unsurlarda yer alan hayali uzamlarla başlamış, filmlerle, fotoğraflarla, dijital bilgi ağlarıyla devam etmiștir. Kellerman'a göre (Kellerman, 2016, s. 23) televizyon, radyo gibi iletişim araçlarıyla başlayan, cep telefonlarıyla devam eden ve internetle zirveye çıkan siber uzam, sanal uzamın bir alt kümesi olarak konumlanmıştır. Siber uzam dairesinin içerisinde ise e-mail, web 2.0 gibi daha çok tek yönlü iletişimin mümkün olduğu internet ve son olarak özellikle sosyal medya ağlarıyla birlikte ortaya çıkan ekran uzamı yer almaktadır ki, söz konusu ekran uzamı, ekranla kullanıcı arasında bir arayüz vazifesi görmektedir. Elektronik bir multimedya sitemine bağlı olarak ortaya çıkan sanallık kültürünün günümüz toplumlarına yansıması ise Castells'e göre $(2008$, s. 609-610) iki şekilde mümkün olmaktadır: eşzamanlılık ve zamansızlık. Eşzamanlığın ve zamansızlığın somutlaştığı siber uzamın en belirgin yönü, insanları fiziksel dünyadaki sinırlılıklardan görece uzaklaştırarak ve yeni bir düzleme yerleştirerek, literatürdeki kavramla, onların tele-varoluşlarını sağlamaktır. Televaroluş, bireylerin gündelik hayattaki fiziki bulunuşlarından farklı bir bulunuş şekliyle siber uzamda yer almasını imleyen bir kavramdır. Karşılıklı etkileşimi mümkün kılan bilgisayar aracılı iletişimin, mekânsal birlikteliği olmayan insanların sohbet edebilmesine imkân tanıması onun eşzamanlı oluşuna örnektir. Diğer taraftan aynı ağ içerisinde eğitimden eğlenceye, haberlerden reklamlara çoklu tercihler arasından birinin seçilme zorunluluğu, kültürel pek çok unsurun zamansız şekilde sıralanması problemiyle yüzleştirir. Alfabetik olarak düzenlenen ansiklopedilerin yerini, medya tüketicilerinin güdülerine ya da üreticilerin arzularına göre düzenlenen elektronik medya almış ve böylece anlamlı olaylar kendi iç kronolojik ritmini kaybetmiştir. Marshall McLuhan'ın içe patlama tanımlamasını kullanarak postmodern dünyada imaj ile gerçeklik arasındaki sınırın infilak edip içe göçtüğünü söyleyen (Best; Kellner, 2011, s. 149) Baudrillard'a göre (2012, s. 71) günümüzde gerçeğin yerini artık sanal almıştır. Çünkü sanal, gerçek dünyayı kusursuz haliyle yeniden üretmekte ve gerçekliğe son vermektedir (Baudrillard, 2005, s. 54). Bu uzamın gerçekle irtibatının kalmaması, bizi bu gerçeğe götüren göstergelerin de ortadan kalktığı anlamına gelir ki (Baudrillard, 2012, s. 65) bunun karşılığı simülasyon çağıdır: 'Bir köken ya da gerçeklikten yoksun gerçeğin, modeller aracılığıyla türetilmesi sonucu' ortaya çıkan simülasyon ya da hipergerçeklik çağında, bundan böyle gerçeğin yerini alan ve gerçekten daha gerçek hale gelen simülakrlar var olacaktır (Baudrillard, 2003, s. 14). Sanal gerçeklik ile gerçek zaman arasında belirgin bir fark olduğuna dikkat çeken Poster, sanal gerçeklik kavramının, gerçekliğin çoklu oluşuna karşılık geleceğini, dolayısıyla gerçekliğin siber uzamda birden fazla şekle bürünebileceğini ifade eder (Poster, 2017, s. 118). Zizek (2011: 197), bireylerin siber uzamda yaşadığı gerçeklik boşluğu hissini, televaroluşun fiziki mevcudiyet karşısındaki eksik kalışından değil, tam tersine siber uzamın simgesel bakımdan aşırı doluşuna bağlayarak Baudrillard'la benzer bir görüş 
ortaya koyar. Castells ise bu konuda daha ılımlı bir fikir öne sürerek, bütün toplumlarda insanoğlunun sembolik bir ortam içinde var olduğunu ve sembolik bir ortam aracılığıyla hareket ettiğini öne sürerek, yeni iletişim sistemlerinin sanal gerçekliği değil, gerçek sanallığı tesis ettiğini belirtir. Medya eleștirmenleri, ona göre, yeni sembolik ortamın gerçek olmadı̆̆ını savunduklarında, aslında örtülü biçimde şifrelenmemiş gerçek deneyime atıfta bulunurlar; fakat böyle bir deneyim hiçbir zaman var olmamıştır. Zira karşılıklı etkileşimde, bütün sembollerin, kendisine atfedilen anlamla ilişkili olarak kısmi değişime uğramaları kaçınılmazdır (Castells, 2008: 497-498).

\section{Sonuç}

Sosyalleşme gerek birey ve gerek toplum açısından önemli bir sürecin ismi olarak anlam ve değer kazanmaktadır. Birey, sosyalleşme sürecinde toplumunun tipik bir üyesi olurken aynı zamanda kimlik ve kişiliği de inşa olmaktadır. Toplum ise zamandaki sürekliliğini, sosyalleşme üzerinden kazandığı bireylerle gerçekleştirmekte, her yeni kuşak bu süreklilikte önemli bir halkayı teşkil etmektedir. Sosyalleşme kendi içerisinde farklı kategorilere ve işlevleri açısından da farklı düzlemlere ayrılabilmektedir. Fakat tüm bunlar içerisinde en önemlisini 'birincil sosyalleşme' ve 'ikincil sosyalleşme' oluşturmaktadır. Birincil sosyalleşmenin gerçekleştiği toplumsal ve bireysel şartlar ile ikincil sosyalleşmenin gerçekleştiği ortam ve durumun şartları birbirinden oldukça faklıdır. Birincil sosyalleşme sürecin temel dinamiği olarak işlev görüp bireyin kimlik ve kişiliğinin omurgasını teşkil ederken, ikincil sosyalleşme ise sürecin toplumsal detaylarını teşkil etmektedir.

Sosyalleşme süreninin en önemli aracı ve ortamı iletişim araçları ve bu araçlar üzerinden inşa olunan ortamdır. İnsanlık yakın zamana kadar sosyalleşmesinde özellikle sözlü iletişimi takiben de yazılı iletişimi kullandı. Ancak geleneksel medya olarak isimlendirilen ve uzakları yakın eden, hedef kitleyi büyülten iletişim teknolojilerinin icadıyla birlikte sosyalleşmenin niceliğinde ve niteliğinde önemli değişmeler gerçekleşti. Bireylerin sosyalleşmesinde aile, arkadaş çevresi, okul gibi unsur ve araçların yerini bu iletişim teknolojileri aldı. Bu süreçte bilhassa televizyon çok etkili oldu. Ancak radikal değişim internet teknolojisiyle gerçekleşti. İnternet teknolojisi sosyalleşme sürecinin işleyişinin yanı sıra niteliğinde de devrimsel nitelikte değișikliklere ve yeni oluşumlar imkân sağladı. Sosyal medya ise bu sürecin en önemli mecrası olarak işlev gördü ve görme ye de devam ediyor. Gerçekleşen değişim ve oluşumun temelinde, en eski çağlardan beri var olan sosyalleşmedeki temel unsurlardan zaman, mekân ve kimlik unsurlarının nesnel bir sabiteye sahip olmasının yeni bir nitelik kazanması vardır. Artık zaman, mekân ve kimlikler sanallaşmıştır. $\mathrm{Bu}$ ise sanal sosyalleşme denilen bir olgunun oluşumuna imkân sağlamaktadır. Bireyler sanal mekândaki sanal kimlikler evreninde kendilerine yer bulmaya çalışırlarken, aynı zamanda 'sosyalleşmiş' de olmaktadırlar. Fakat bu 'sosyalleşme' sırtını yalnızlığı, tekilliğe dayamış ve sosyal açılımı ya hiç olmayan ya da tamamen kurgulanmış olup nesnel gerçekliği olmayan türden bir sosyalleşmedir.

\section{Kaynaklar}

Acun, R. (2011). Her dem yeniden doğmak: online sosyal ağlar ve kimlik. Millî Folklor, 23(89), 66-77.

Borlandi, M ve Boudun, R.vd. (2011). Sosyolojik düşünce sözlüğü. (B. Arıbaş, Çev.), İstanbul: İletişim Yayınları.

Curtiss, S. (1977). Genie -A psycholinguistics study of a modern- day. Vild Child, New York: Academic Press. 
Edgar, A. ve Sedgwick, P. (2007). Kültürel kuramda anahtar kavramlar. (M. Karaşahan, Çev.), İstanbul: Açılım Kitap Yayınları.

Elkin, F. (1995). Çocuk ve toplum (N. Güngör, Çev.), Ankara: Gündoğan Yayınları.

Ergenç, A. (2011). Web 2.0 ve sanal sosyalleşme: facebook örneği. (Yüksek Lisans Tezi). Maltepe Üniversitesi Sosyal Bilimler Enstitüsü, İstanbul.

Ergil, D. (1984). Toplum ve insan, Ankara: Turhan Kitapevi.

Friedman, T. (2006). Dünya düzdür. (L. Cinemre, Çev.), İstanbul: Boyner Yayınları.

Hennig, T., vd. (2010). The impact of new media on customer relationships. Journal of Service Research, 13 (3), 310-326.

Laughey, D. (2010). Medya çalışmaları: teoriler ve yaklaşımlar. (A. Toprak, Çev.), İstanbul: Kalkedon Yayınları.

Marshall, G. (1999), Sosyoloji sözlüğü. (O. Akınhay, D. Kömürcü, Çev.), Ankara: Bilim ve Sanat Yayınları.

Mayfield, A. (2010). What is social media. icrossing. e-book. Erişim adresi (12/12/2019): http://www. icrossing

McLuhan, M. (2011). Gutenberg galaksisi, (G. Çağalı, Çev.), İstanbul: Yapı Kredi Yayınları.

Neumann, E.N. (1993). The sprial of silence, Chicago: University of Chicago Press.

Ong, W. J. (2018). Sözlü ve yazılı kültür, sözün teknolojikleşmesi, (S. Postacığlu, Çev.), İstanbul: Metis Yayınları.

Özkalp, E. (2010). Sosyolojiye giriş, Bursa: Ekin yayınları.

Öztürk, M.C. (Ed.). (2013). Dijital iletişim ve yeni medya. Eskişehir: Anadolu Üniversitesi Yayınları.

Rigel, N. (1994). Medya ninnileri, İstanbul: Sistem Yayıncılık.

Robertson, A. (1999). Küreselleşme. (H. Yolsal, Çev.), Ankara: Bilim ve Sanat Yayınları.

Robins, K. (1999). İmaj- görmenin kültür ve politikası. (H. Erbaş, Çev.), Ankara: Gündoğan Yayınları.

Sekam, (2011), Türkiye'de aile, İstanbul: Sekam Yayanları.

Sennett, R. (2013). Kamusal insanın çöküşü, (S. Durak, A. Yılmaz, Çev.), İstanbul: Ayrıntı Yayınları.

Sezal, İ. (2003). Sosyolojiye giriş, Mersin: Martı Kitabevi.

Tolan, B. (1991). Sosyal psikoloji, Ankara: Adım Yayıncılık.

Toruk, İ., (2008), Üniversite gençliğinin medya kullanma alışkanlıkları üzerine bir analiz. Selçuk üniversitesi sosyal bilimler enstitüsü dergisi, (19), 475-488.

Uluç, G. (2003). Küreselleşen medya: iktidar ve mücadele alanı, İstanbul: Anahtar Kitaplar Yayınevi.

Ülgen, G. (1983). Çocuk gelişimi, İstanbul: Milli Eğitim Bakanlığı Yayınları

Willems, E. (1961). Dictionnaire de sociologie, Paris: Librairie Marcel Rivière.

Yavuzer, H. (1986). Aile ve çocuk, İstanbul: Ak Yayınları.

Zizek, S. (2011). Kırılgan Temas. T. Birkan (Çev), İstanbul: Metis Yayınları. 


\title{
Socialization, and The Conceptual and Functional Transformation of Socialization in Social Media Channels
}

\author{
Saniye Vatandaş (Lect. Ph.D.)
}

\section{Extended Abstract}

Man is a social being by nature. Living outside the community alone makes it impossible for him to meet his biological, psychological, and social needs. Even if the basic material needs for maintaining his biological existence are met, he cannot acquire the most basic human characteristics. For instance, he cannot speak, communicate, control his emotions, and realize his mental development; he will experience mental retardation. In fact, birth is only one of the essential stages in all phases of human development; man is an incomplete being in many aspects at the time of birth. Only the most basic requirements of biological development have been completed when he is born. In addition to the incomplete dimensions of his biological existence, his psychological and social development take place after birth. In other words, the formation and development of the bodily, mental, emotional, and behavioral characteristics of man take place in two different environments: in his mother's body and in the social structure. It is possible for the human baby to complete the biological, psychological, and social deficiencies and to become a 'normal' person at every stage of life by continuing his development in the social structure after he is born. The first phase lasts nine months, and the second phase lasts throughout life. The survival of the child who has not completed the necessary biological development in the womb is either impossible or the cause of severe biological problems, depending on the nature of the deficiency. An individual who has not completed his development within the social structure and the network of relations that are dominant in this structure leads to significant psychological and social problems in terms of both the individual and society. Therefore, every individual is present in the social environment and takes his place in the network of social relations. In other words, they are included in the socialization process.

Particular prerequisites are necessary for the human baby, who is born with the potential of socialization and has to socialize by nature, in order to become a member of the society in which he is born. The first one is the existence of a social structure that is both the cradle and the goal of socialization. An individual can socialize only in a social structure by taking part in the network of relationships in that structure, because socialization is not an abstract information process but a process that is realized by experiencing. The second prerequisite for the realization of socialization is that the child must have the necessary and sufficient biological and hereditary characteristics to ensure that he socializes and becomes a member of the society. Those who have significant hereditary disorders cannot socialize at all or face severe problems in their mental, emotional, and behavioral development. For instance, it is either extremely difficult or utterly impossible for a child with significant mental disability to socialize to their full potential. As can be understood from this, our biological existence makes socialization not only possible but also necessary. The third prerequisite of socialization is that an individual must have the desire to establish some relationships with the other individuals and make efforts in this regard. The individual gains experience accompanied by love, respect, compassion, shame, jealousy, loyalty, benevolence, fidelity, pity, appreciation, ungratefulness, selfishness, and so on in these relationships. They act as the cornerstones of being a special person rather 
than being an ordinary individual. Socialization has many functions: the first one of these functions is the individual's becoming an appropriate member of the society.

Socialization is the name of the process in which an individual learns to become a member of a particular society and hence its culture, to become a truly social and cultural being, and to fulfill its requirements to a large extent. In this process, the individual becomes a 'normal' member of the society by internalizing the norms and values of the society as well as learning to fulfill their social roles (as a worker, friend, citizen, son, wife, mother, father, and so on.) and the requirements of these roles. However, the same social environment does not lead to the formation of individuals with identical personalities. Inborn genetic characteristics, qualifications of the social units, of which individuals are members, differences in individual and social relationships, and many other known and unknown factors cause the individuals to have different personalities from one another. However, personality differences are a matter of detail for the society. Even if there are personality differences among the individuals who are the members of a society, individuals generally have similarities in terms of personality characteristics and lifestyles. This becomes significant as the reason for the differences among societies.

The environments and units that affect the socialization process are not structurally and functionally stable. They can change in terms of number as well as function. The family institution is an essential example of functional change. The family institution has changed significantly both quantitatively and qualitatively over time. This change has altered the impact power and rate of the family, which is the most critical factor of socialization, in the socialization of the individual because the contribution of the large family structure to the socialization of the individual and the effect of the nuclear family on it are not the same. Besides, the school (educational institution), which could not take part in a significant part of the human history, becomes significant as an example of the numerical increase in the factors of socialization, just like means of mass communication. This shows that the gaps caused by the change of social institutions and units that provide socialization in the historical process or the new opportunities and lifestyles formed by technological development lead to numerical and functional changes in the factors of the socialization process. They can even lead to changes in socialization itself. From this point of view, the effect of the channels of social media, which are the products of internet technology, on the personality development of individuals is essential. As of the last stage we have reached today, it is possible to mention the virtualization of socialization, in other words, virtual socialization. It is now possible to mention not only the change in the factors that provide socialization but also the qualitative change that takes place more in the socialization itself. Changes and new formations caused by virtual socialization in terms of the individual and society are vital problems themselves.

Keywords: Socialization, Social Media, Virtualization. 